\title{
Second Generation Bioethanol Production from Lignocellulosic Waste and Its Future Perspectives: A Review
}

\author{
Nisha Sharma* and Nivedita Sharma \\ Microbiology Research Laboratory, Department of Basic Science, Dr Y S Parmar University \\ of Horticulture and Forestry, Nauni, Solan (HP) - 173230, India \\ *Corresponding author
}

\section{A B S T R A C T}

\begin{tabular}{|l|}
\hline Ke y w o r d s \\
Lignocellulosic biomass, \\
Bioethanol, Second \\
generation
\end{tabular}

Lignocellulosic biomass bioethanol production, commonly referred to as Second Generation biofuels, using agricultural residues, forest residues, energy feedstocks, municipalities, and other waste crop solids is considered as a promising alternative energy source in order to minimize reliance on limited fossil sources, greenhouse gas emissions, and environmental pollutions. Bioethanol from food based materials may lead to "food vs fuel" conflict with the increase of world population. Corn and sugar based ethanol are promising substitute to gasoline production in transportation sector, are not sufficient to replace global fossil fuel consumption each year. Lignocellulosic biomass serves as a potential source for the production of second generation bioethanol. The present paper represents an overview on the bioethanol production from different substrates. It reviews information about current practices and also suggests future prospects.

\section{Introduction}

Biofuels are referred to solid, liquid or gaseous fuels derived from organic matter. They are generally divided into primary and secondary biofuels. While primary biofuels such as fuel wood are used in an unprocessed form primarily for heating, cooking or electricity production, secondary biofuels such as bioethanol and biodiesel are produced by processing biomass and are able to be used in vehicles and various industrial processes. Today's society is based on the use of fossil resources for transportation fuels and petrochemicals. Energy sources and their utilization determine the economic status and growth of developing countries all over the world (Xu et al., 2009). The demand for energy is growing globally due to expanding human population and increase in industrial prosperity. The conventional fossil such as oil, coal and natural gas still constitute the major source of energy. The continuous utilization of fossil fuels over the years has severely augmented the concentration of greenhouse gases in the atmosphere of earth (Ballesteros et al., 2006). Depleting fossil reserves and increasing demand for energy together with environmental concerns have led to focused research on the development of alternative fuels which are eco-friendly, biodegradable and economical. The use of renewable resources to produce liquid biofuels offer attractive solutions to reducing 
greenhouse gas emissions, decreasing reliance on foreign oils, addressing energy security concerns, strengthening rural and agricultural economies and increasing the sustainability of the world transportation system (Demirbas, 2007). Bioethanol is one such dominant global renewable transport biofuel which can readily substitute fossil fuels. Conventionally, bioethanol has been produced from sucrose and starch rich feedstocks (edible agricultural crops and products) known as first generation bioethanol; however this substrate conflicts with food and feed production. As an alternative to first generation bioethanol, currently there is much focus on advancing a cellulosic bioethanol concept that utilizes lignocellulosic residues from agricultural crops and residues (such as bagasse, straw, stover, stems, leaves and deoiled seed residues). Lignocellulosic materials are cheap renewable resources, available in large quantities (Millati et al., 2002). Lignocellulosic waste materials obtained from energy crops, wood and agricultural residues represent the most abundant global source of renewable biomass (Lin and Tanaka, 2006). Efficient conversion of lignocellulosic biomass into bioethanol remains an area of active research in terms of pretreatment of the biomass to fractionate its constituents (cellulose, hemicellulose and lignin), breakdown of cellulose and hemicellulose into hexose and pentose sugars and cofermentation of the sugars to ethanol. The present review describes the overall conversion process of lignocellulosic waste into bio-ethanol and economics and environment involved in bioethanol production from lignocellulosic waste.

\section{Current status in India}

India is now a days showing interest towards use of ethanol as an automotive fuel. A tremendous contribution has been made by distilleries in India. They are using this surplus alcohol as a blending agent or an oxygenate in gasoline. The 5\% ethanoldoped-petrol in vehicles now has been confirmed by Society for Indian Automobile Manufacturers (SIAM). State Governments of major sugar producing States and the representatives of sugar/distillery industries also confirmed availability/capacity to produce ethanol. In the 2006 ethanol demand was 0.64 billion liters at $5 \%$ gasoline doping levels while the approximately about 1.5 billion liters will be required for $10 \%$ blending of entire gasoline sold in India (Tiwari et al., 2015). This demand will be projected to 2.2 billion liters in 2017. Indian alcohol industry is fairly mature with 295 distilleries established all across the country with an annual capacity of 3.2 billion liters.

\section{First generation Vs second generation}

Most current bioethanol production processes utilize more readily degradable biomass feedstocks such as cereals and sugarcane juices. However the utilization of edible agricultural crops exclusively for biofuel production conflict with food and feed production (Wheals et al., 1999). The bioethanol produced from these sucrose and starch containing feedstocks is classified as first generation bioethanol and those produced utilizing cellulosic feedstock is second generation bioethanol (Muktham et al., 2016). Lignocellulosic biomass represents a promising resource for bioethanol production which is renewable in nature. Not only an energy source, biomass is also a promising raw material for the production of chemicals (Werpy et al., 2004). The advent of second generation biofuels is intended to produce fuels from lignocellulosic biomass, the woody part of plants that do not compete with food production. Sources include agricultural residues, forest harvesting residues or wood processing waste such as leaves, straw or wood chips as well as the non-edible 
components of corn or sugarcane (Brennam et al., 2010). Therefore, third generation biofuels derived from microalgae are considered to be a viable alternative energy resource that is devoid of the major drawbacks associated with first and second generation biofuels (Nigam and Singh, 2010). Microalgae are able to produce 15-300 times more oil for biodiesel production than traditional crops on an area basis. This article focuses on microalgae as a potential source of biodiesel. The species of algae suitable for lipids production are the microalgae (phytoplankton or microphytes). The macro algae or seaweed, on the other hand have many commercial values but not for lipid production. Other commercial values of algae include the making of food ingredients such as omega3 fatty acids, fertilizer, chemical feedstock, pharmaceuticals and bioplastics. A microalga is classified as diatoms (bacillariophyceae), green algae (chlorophyceae), goldenbrown (chrysophyceae) and blue-green algae (cyanophyceae) (Karthikeyan et al., 2012).

\section{Bioconversion processes}

Existing ethanol production processes have: Separate hydrolysis and fermentation (SHF) (Sharma and Sharma, 2016a), Simultaneous saccharification and fermentation (SSF), Simultaneous saccharification and cofermentation (SSCF) (Sharma and Sharma, 2016b), consolidated bioprocessing step (CBP). Consolidated is cost effective process as the processes namely enzyme production, hydrolysis and fermentation taking place within the same bioreactor making the capital cost lower (Olson et al., 2012). Bioethanol production from lignocellulosic biomass involves various steps: (i) Pretreatment: The main aim of lignocellulosic biomass pretreatment is to separate the biomass components i.e. cellulose, hemicellulose and lignin. A number of techniques are available for the pretreatments of biomass; these includes hot water treatment (Weil et al., 1997), steam explosion (Sun and Cheng, 2002), ammonia fibre explosion (Mc Millan et al., 1994), organic solvent treatment (Pan et $a l ., 2005)$, acid and alkaline treatments and biological pretreatments. (ii) Enzymatic hydrolysis: Breakdown of polymeric carbohydrates into simple sugars that can be fermented by microorganisms into ethanol. (iii) Fermentation: Conversion of carbohydrates into ethanol by selected ethanologens. (iv) Downstream processing: Recovery of ethanol from fermentation broth and management of the remaining streams.

\section{Microorganisms for bioethanol production}

Ethanol is produced primarily by the fermentation of glucose liberated from cellulosic feedstock using fermentative microorganisms, principally yeasts, Saccharomyces cerevisiae (Demirbas, 2005). The most common microbe used has been $S$. cerevisiae which, as Lin and Tanaka, (2006) produced ethanol at concentrations as high as $18 \%$ in the fermentation broth. It is a relatively easy microbe to handle as it is generally recognized as safe. Zymomonas mobilis, a Gram-negative bacterium, can also be used in fermentation of glucose into ethanol (Dien et al., 2003). Biomass formed during fermentation using $S$. cerevisiae and Zymomonas mobilis are recognized as safe for fodder, making these organisms suitable for metabolic engineering for application in cofermentation of both pentose and hexose sugars. Recent reports suggest that some white rot fungi namely Agaricus bisporus, Bjerkandera adusta and Iprex lacteus are able to produce ethanol from glucose under semiaerobic conditions (Saha et al., 2016). Sharma and Sharma (2016) used various combinations of ethanologens i.e. monoculture as well as co-culture and the best co-culture combination was $S$. cerevisiae + Pichia 
stipitis $\quad(18.47 \mathrm{~g} / \mathrm{l} \quad$ ethanol with $72.46 \%$ fermentation efficiency) (Sharma and Sharma, 2016c)

\section{Enzymes in bioethanol production (cellulases)}

Enzymatic saccharification of lignocellulosic materials such as sugarcane bagasse, corncob, rice straw, switch grass, saw dust, and forest residues by cellulases for biofuel production is perhaps the most popular application currently being investigated. Cellulases are the enzymes involved in the degradation of lignocellulosic biomass (Pandey, 2015).

Bioconversion of lignocellulosic materials into useful and higher value products normally requires multistep processes. These processes include; pretreatment, hydrolysis of the polymers to produce readily metabolizable molecules (e.g., hexose and pentose sugars), bioconversion of these smaller molecules to support microbial growth and/or produce chemical products, and the separation and purification of the desired products.

\section{Advantages/uses of bioethanol}

Bioethanol has mostly been used as a bio fuel for transport, as it is blended with petrol at $5 \%$ and in some countries at $10 \%$ level. Ethanol is also being used to formulate a blend with diesel fuel, known as "E-Diesel". It is used, for example, in cosmetics, many perfumes, colognes, mouthwash, aftershave lotions, soaps, shampoo etc.

A number of other chemicals such as ethyl esters, ethyl acetate, extractants, antifreeze and intermediates in the synthesis of various organic chemicals are formed by ethanol. Ethyl alcohol is always produced by fermentation of some suitable material to form beer, wine, or distilled spirits of various kinds (Tiwari et al., 2015).

\section{Future perspectives}

Strategies for improving fermentative ethanol production have focused almost exclusively on the development of processes based on the utilization of the carbohydrate fraction of lignocellulosic material. These so-called 'second-generation' technologies require metabolically engineered production strains that possess a high degree of catabolic versatility and are homoethanologenic. For third generation bioethanol from macro algae, especially from brown algae still requires a detailed study of optimization in the steps of hydrolysis and fermentation. However there are still some challenges hampering its production and consequent commercialization.

\section{Acknowledgment}

This study was financially supported by Department of Science and Technology (DST), New Delhi in the form of "INSPIRE FELLOWSHIP", JRF/SRF [IF-110299] and authors gratefully acknowledge the financial support given by DST, New Delhi- India.

\section{References}

Ballesteros, I., Negro, M. J., Oliva, J. M., Cabanas, A., Manzanares, P. and Ballesteros, M. 2006. Ethanol production from steam explosion pretreated wheat straw. Twenty seventh symposium on Biotechnology for fuels and chemicals. Springer. 496-508.

Brennam, L. and Owende, P. 2010. Biofuels from microalgae- A review of technologies for production, processing and extraction of biofuels and coproducts. Renew. Sust. Energ. Rev. 14, 557-577.

Demirbas, A. 2005. Bioethanol from cellulosic materials: A renewable motor 
fuel from biomass. Energ. Sources. 27, 327-337.

Demirbas, A. 2007. Progress and Recent Trends in Biofuels. Prog. Energ. Combust. 33, 1-8.

Dien, B. S., Cotta, M. A. and Jeffries, T. W. 2003. Bacteria engineered for fuel ethanol production: current status. Appl. Microbiol. Biotechnol. 63, 258-266.

Karthikeyan, S. 2012. A critical Review: Microalgae as a renewable source for biofuel production. Int. J. Eng. Res. Technol. 1 (4), 1-6.

Lin, Y. and Tanaka, S. 2006. Ethanol fermentation from biomass resources: current state and prospects. Appl. Microbiol. Biotechnol. 69 (6), 627-642.

Mc Millan, J. D., Himmel, M. E., Baker, J. O. and Overend, R. P. 1994. Pretreatment of lignocellulosic biomass. IN: Himmel, M. E., Baker, J. O. and Overend, R. P., Eds., Enzymatic conversion of biomass for fuels production. American Chemical Society, Washington D.C. 292-324.

Millati, R., Niklasson, C. and Taherzadeh, M. J. 2002. Effect of $\mathrm{pH}$, time and temperature of overliming on detoxification of dilute acid hydrolysates for fermentation by $S$. cerevisiae. Process. Biochem. 38 (4), 515-522.

Muktham, R., Bhargava, S. K., Bankupalli, S. and Ball, A. S. 2016. A Review on $1^{\text {st }}$

Nigam, P. S. and Singh, A. 2011. Production of liquid biofuels from renewable resources. Prog. Energ. Combust. 37, 52-58.

Olson, D.G., Mc Bride, J. E., Shaw, A. J. and Lynd, L. R. 2012. Recent progress in consolidated Bioprocessing. Current Opinion in Biotechnology. 23, 396-405.

Pan, X., Arato, C., Gilkes, N., Gregg, D., Mabee, W., Pye, K., Xiao, Z. and Saddler, J. 2005. Biorefining of softwoods using ethanol oganosolv pulping: preliminary evaluation of process streams for manufacture of fuel grade ethanol and co-products. Biotechnol. Bioeng. 90, 473-481.

Pandey, S. 2015.Cellulases in conversion of lignocellulosic waste into second generation biofuel. International Journal of Advanced Research. 3(7), 392-399.

Saha, B. C., Qureshi, N., Kennedy, G. J. and Cotta, M. A. 2016. Biological pretreatment of corn stover with white rot fungus for improved enzymatic hydrolysis. Int. Biodeter. Biodegr. 109, 29-35.

Sharma, N. and Sharma, N. 2016a. Bioethanol production from alkaline hydrogen peroxide pretreated Populus deltoides wood using hydrolytic enzymes of Bacillus stratosphericus N12 (M) and Bacillus altitudinis $\mathrm{Kd} 1$ (M) under different modes of separate hydrolysis and fermentation by mono culture and co-culture combinations of ethanologens. International Journal of Bioassays. 5(2), 4810-4816.

Sharma, N. and Sharma, N. $2016 \mathrm{~b}$. Bioethanol production under simultaneous saccharification and fermentation (SSF) and simultaneous saccharification and co- fermentation (SSCF) as well as its scale up in a stirred tank bioreactor. International Journal of Innovative Research in Science, Engineering and Technology. 5(2), 1572-1576.

Sharma, N. and Sharma, N. 2016c. Bioethanol production from $\mathrm{NaOH}+\mathrm{H}_{2} \mathrm{O}_{2}$ pretreated Populus deltoides wood using cocktail of in house and commercial enzyme under four different modes of separate hydrolysis and fermentation. World Journal of Pharmaceutical Research. 5(2), 661-676.

Sun, Y. and Chen, J. 2002. Hydrolysis of lignocellulosic materials for ethanol 
production: A Review. Bioresour. Werpy, T. and Petersen, G. 2004. Top value Technol. 83, 1-11. added chemicals from Biomass. National Renewable Energy Laboratory.

Tiwari G., Shivangi, Sharma, S. and Prasad, R. 2015. Bioethanol production: Future Prospects from non- additional sources in India. Int. J. Res. Biosci. 4 (4), 1-15.

Weil, J. R., Sarikaya, A., Rau, S. L., Goetz, J., Ladisch, C. M., Brewer, M., Hendrickson, R. and Ladisch, M. R. 1997. Pretreatment of yellow poplar sawdust by pressure cooking in water. Appl. Biochem. Biotechnol. 68, 21-40.

Wheals, A. E., Basso, L.C., Alves, D. M. G. and Amorim, H. V. 1999. Fuel ethanol after 25 years. Trends. Biotechnol. 17, 482-487.

Xu, Y., and Liu, H. Y. 2009. Development and expectation of the energy plant. Chinese Agricultural Science Bulletin. 25, 297-300.

\section{How to cite this article:}

Nisha Sharma and Nivedita Sharma. 2018. Second Generation Bioethanol Production from Lignocellulosic Waste and Its Future Perspectives: A Review. Int.J.Curr.Microbiol.App.Sci. 7(05): 1285-1290. doi: https://doi.org/10.20546/ijcmas.2018.705.155 